\title{
Pengungkapan Corporate Social Responsibility Sebagai Pemoderasi Pengaruh Leverage dan Kepemilikan Manajerial Pada Nilai Perusahaan
}

\author{
Ida Ayu Gde Shinta Vidarani ${ }^{1}$ \\ Fakultas Ekonomi dan Bisnis \\ Universitas Udayana, Indonesia \\ Email: idaayushintavidarani@gmail.com
}

\author{
I Gusti Ayu Nyoman Budiasih² \\ Fakultas Ekonomi dan Bisnis \\ Universitas Udayana, Indonesia
}

\begin{abstract}
ABSTRAK
Penelitian ini bertujuan untuk mengetahui dan mendapatkan bukti empiris mengenai pengungkapan Corporate Social Responsibility sebagai pemoderasi pengaruh leverage dan kepemilikan manajerial pada nilai perusahaan. Penelitian ini dilakukan pada perusahaan. pertambangan yang terdaftar di Bursa Efek Indonesia (BEI) Tahun 2014-2018. Sampel penelitian ini dipilih menggunakan metode nonprobability sampling dengan teknik purposive sampling dan diperoleh sebanyak 13 perusahaan pertambangan, sehingga jumlah pengamatan dalam penelitian sebanyak 65 amatan selama 5 tahun. Teknik analisis data yang digunakan adalah Moderated Regression Analysis (MRA). Berdasarkan hasil penelitian, menunjukkan bahwa pengungkapan Corporate Social Responsibility sebagai variabel moderasi memperlemah pengaruh leverage pada nilai perusahaan, pengungkapan Corporate Social Responsibility sebagai variabel moderasi yang memperkuat pengaruh kepemilikan manajerial pada nilai perusahaan.
\end{abstract}

Kata Kunci: Pengungkapan CSR; leverage; kepemilikan manajerial; nilai perusahaan.

\section{Corporate Social .Responsibility Disclosure As} Moderating Effects of Leverage and Managerial Ownership on Firm Value

\begin{abstract}
This study aims to determine and obtain empirical evidence regarding the Corporate Social Responsibility disclosure as a moderating effect of leverage and managerial ownership on firm value. This research was conducted on mining companies. listed on the Indonesia Stock Exchange in 2014-2018. The research sample was selected using the nonprobability sampling method with a purposive sampling technique and obtained 13 mining companies, so the number of observations in the study was 65 observations over 5 years. Data analysis techniques used is Moderated Regression Analysis (MRA) based on the results of the study, it shows that corporate social responsibility disclosure as a moderating variable that weakens the influence of leverage on firm value, corporate social responsibility disclosure as a moderating variable that strengthen the influence of managerial ownership on firm value.
\end{abstract}

Keywords: $\quad$ CSR Disclosure; Leverage; Managerial Ownership; Firm Value.

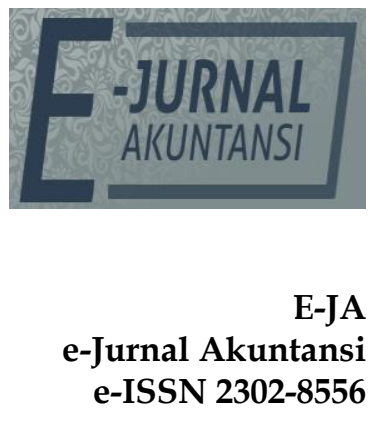

Vol. 30 No. 1

Denpasar, Januari 2020

Hal. 147-162

Artikel Masuk: 15 Oktober 2019

Tanggal Diterima: 30 November 2019 


\section{PENDAHULUAN}

Nilai perusahaan merupakan penghargaan yang diperoleh oleh suatu perusahaan dari masyarakat atas kinerja dan prestasi yang diraih perusahaan dalam melayani para pemangku kepentingan. Nilai perusahaan merupakan persepsi investor pada.tingkat keberhasilan perusahaan agar dapat. memberikan kemakmuran untuk para pemegang saham secara .maksimum dengan meningkatkan harga saham. perusahaan (Indasari \& Yadnyana, 2018). Theory of the firm menjelaskan bahwa tujuan utama perusahaan adalah memaksimalkan nilai perusahaan, dimana nilai perusahaan tercermin melalui harga sahamnya (Fama \& French, 2007). Naik turunnya nilai perusahaan dapat dilihat dari harga sahamnya. Perusahaan yang memiliki kinerja keuangan yang baik, mengakibatkan sahamnya banyak diminati oleh investor dimana dapat dilihat dari laporan keuangan yang dipublikasikan oleh perusahaan. Dengann adanya peluang investasi dapat memberikan sinyal yang baik mengenai pertumbuhan perusahaan sehingga dapat meningkatkan nilai perusahaan. Pemilihan penelitian pada perusahaan pertambangan di BEI dikarenakan perusahaan pertambangan adalah salah satu jenis perusahaan. yang nilai perusahaannya.dipengaruhi. oleh pandangan publik di dalam melakukan aktivitasnya. Perusahaan Pertambangan yang listing di BEI selalu bertambah setiap tahunnya sejak tahun 2014 sampai tahun 2018. Hal ini mengindikasikan bahwa perusahaan sektor pertambangan memiliki prospek yang baik untuk terus berkembang sehinga menarik untuk diteliti.

Perkembangan pada sektor pertambangan akan selalu diikuti adanya persaingan yang ketat antar perusahaan demi tercapainya tujuan perusahaan. Di dalam menjalankan operasi bisnis, perusahaan tentu saja akan dihadapkan pada situasi di mana nilai perusahaan akan meningkat atau bahkan menurun. Seperti halnya fenomena yang terjadi mengenai indeks harga saham perusahaan pertambangan yang terjadi pada tahun 2015. Pada tahun 2015 inilah, sektor pertambangan memiliki bobot terendah, dimana indeks saham sektor pertambangan merosot hingga 2,97 persen. Padahal, pada tahun 2014 indeks pertambangan memiliki bobot 5,15 persen. Artinya, ada sentimen negatif yang membuat saham pertambangan anjlok cukup tajam pada tahun 2015. Pada tahun yang sama, Indeks Harga Saham Gabungan (IHSG ) juga menurun 25,4 persen ke titik terendahnya di level 4.120,503 pada bulan September 2015. Pada bulan oktober 2018 indeks harga saham pertambangan tercatat mengalami pelemahan, dimana tercatat turun 0,7 persen, sejalan dengan IHSG yang menyusut 0,12 persen ke level 5.702,38. Penurunan saham terjadi pada PT Aneka Tambang Tbk yang menurun 2.03 persen ke level harga Rp 725 per saham. Selain itu saham PT Adaro Energy Tbk juga turun 1,5 persen ke level Rp 2.210 per saham (www.cnbcindonesia.com). Berikut data mengenai pergerakan nilai perusahaan pada perusahaan pertambangan yang terdaftar di BEI tahun 2014 - 2018 yang ditunjukkan pada Gambar 1 berikut. 


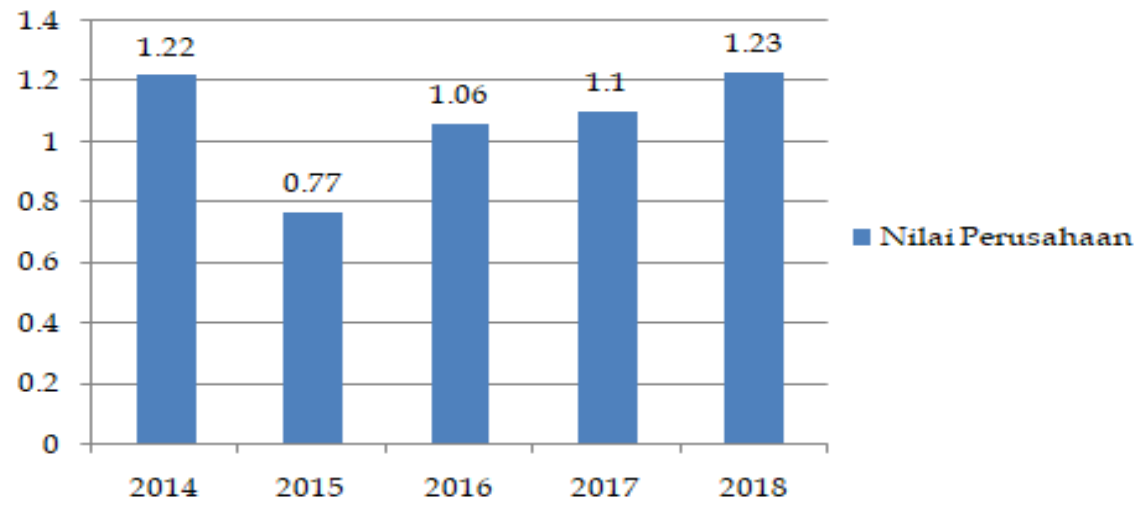

\section{Gambar 1. Grafik .Nilai.Perusahaan pada Perusahaan Pertambangan yang} terdaftar di BEI Periode 2014-2018

\section{Sumber: Data Penelitian, 2019}

Berdasarkan Gambar 1. dapat dilihat bahwa adanya penurunan nilai perusahaan pertambangan tahun 2015 sebagai akibat dari adanya krisis ekonomi global. Pada tahun 2015 rata-rata nilai perusahaan pertambangan mengalami penurunan yang sangat signifikan yaitu sebesar 0,45 , sebelumnya nilai perusahaan tahun 2014 sebesar 1,22 turun menjadi 0,77 di tahun 2015. Pada tahun 2016 nilai perusahaan mengalami peningkatan 0,29 dari tahun 2015. Tahun 2017 rata-rata nilai perusahaan sebesar 1,10 dan tahun 2018 meningkat sebesar 1,23 . Naik turunnya nilai perusahaan inilah yang mendasari untuk dilakukannya penelitian mengenai faktor-faktor apa yang memengaruhi nilai perusahaan pada perusahaan pertambangan.

Salah satu faktor yang dapat mempengaruhi nilai perusahaan adalah leverage. Leverage merupakan suatu rasio keuangan yang mengukur seberapa banyak perusahaan dibiayai dengan menggunakan utang (Wiagustini, 2010). Teori agency memiliki prinsip utama yaitu adanya hubungan antara principal dan agent. Dikaitkan dengan leverage, dalam hal ini terdapat hubungan keagenan antara manajemen dengan kreditur dimana hubungan ini muncul sebagai dampak dari adanya debt convenant hypothesis yang menyatakan bahwa perusahaan yang mempunyai rasio antara utang dan ekuitas, lebih besar maka semakin dekat perusahaan terhadap kendala dalam perjanjian utang (Kalay, 1982). Penggunaan utang di dalam struktur modal perusahaan ditunjukkan untuk mengurangi adanya masalah keagenan di dalam perusahaan. Penggunaan utang dengan proporsi yang tepat akan membantu perusahaan dalam mencapai tingkat struktur modal yang optimal dan meningkatkan nilai perusahaan. Leverage yang semakin besar menunjukkan investasi yang semakin besar juga sebaliknya, perusahaan dengan leverage yang rendah memiliki risiko yang rendah juga. Peningkatan leverage dapat memberikan. sinyal. baik (goodnews) dan sinyal. buruk (badnews).

Faktor lain yang memengaruhi nilai perusahaan yaitu kepemilikan manajerial. Kepemilikan manajerial adalah kepemilikan saham oleh pihak manajemen perusahaan. Dalam meningkatkan nilai. perusahaan, sering. terjadi adanya konflik keagenan, yakni konflik kepentingan. antara pemegang saham dan manajer. Manajer perusahaan. cenderung ingin mengejar tujuan. pribadinya untuk mendapatkan bonus. Permasalahan ini muncul karena manajer tidak 
selalu membuat keputusan demi memenuhi kepentingan terbaik pemegang saham. Hubungan antara pemegang saham dengan manajer pada suatu perusahaan dapat mengarah pada munculnya ketidakmerataan informasi (information asymmetry) yang dimiliki antara pemegang saham dengan manajer. Sebagai pihak yang menjalankan perusahaan, agen memiliki akses yang lebih banyak terhadap informasi perusahaan dan menginginkan sesuatu yang lebih untuk kepentingan pribadi dengan tidak mengungkapkan suatu informasi kepada prinsipal, sehingga terdapat ketidakseimbangan informasi antara agen dan prinsipal. Situasi seperti ini di mana salah satu pihak memiliki informasi lebih dan terjadi ketidakseimbangan informasi dinamakan dengan asimetri informasi (Boučková, 2015). Dengan manajemen memiliki proporsi saham dalam perusahaaan menjadi salah satu alternatif untuk mengurangi konflik keagenan yang terjadi, karena dengan begitu tujuan agen dan prinsipal sama yaitu meningkatkan nilai perusahaan. Menurut agency theory dengan adanya kepemilikan saham oleh pihak manajemen dapat digunakan untuk mengurangi agency cost yang berpotensi timbul.

Penelitian tentang pengaruh leverage dan kepemilikan manajerial pada nilai perusahaan telah dilakukan oleh beberapa peneliti sebelumnya. Penelitian Mandey et al., (2017), Pratama \& Wiksuana (2016) menemukan bahwa leverage memiliki pengaruh positif signifikan terhadap nilai perusahaan sedangkan penelitian Hargiansyah (2015), Kodongo et al., (2014), Cheryta et al., (2017) menunjukkan bahwa bahwa leverage berpengaruh negatif dan signifikan pada nilai perusahaan. Penelitian Dewi \& Suputra (2018) memperoleh hasil bahwa leverage berpengaruh. negatif. dan tidak signifikan terhadap nilai perusahaan. Penelitian yang dilakukan oleh Astriani (2014), Widyaningsih (2018), Hatem (2015) yang menemukan bahwa kepemilikan manajerial memiliki pengaruh positif pada nilai perusahaan. Sedangkan penelitian dilakukan oleh Hidayah (2015), Hartana \& Putra (2017), Rini Indah et al., (2017) menemukan bahwa kepemilikan manajerial. berpengaruh negatif pada nilai perusahaan.

Berdasarkan hasil penelitian sebelumnya, terjadi hasil yang tidak konsisten mengenai pengaruh leverage dan kepemilikan manajerial pada nilai perusahaan, sehingga pendekatan kontingensi digunakan untuk enyelasikan perbedaan hasil dari penelitian sebelumnya. Menurut Govindarajan (1986), pendekatan kontingensi digunakan untuk menyelesaikan perbedaan hasil dari penelitian tersebut. Pendekatan kontingensi memberikan peluang kepada variabel lain untuk menjadi variabel moderasi yang memengaruhi nilai perusahaan. Penelitian ini mencoba menggunakan Pengungkapan Corporate Social Responsibility sebagai variabel moderasi karena kegiatan Corporate Social Responsibility merupakan bagian dari tata kelola perusahaan yang baik, yang dapat memperkuat atau memperlemah pengaruh leverage dan kepemilikan manajerial pada nilai perusahaan. Menurut teori agensi, CSR memiliki kemampuan sebagai upaya dalam mengurangi.ketidakmerataan informasi sehingga dapat mengurangi adanya agency cost (Tristiarini, 2014). Didasari dengan teori keagenan (agency theory) dengan asumsi hipotesis yaitu the conflictresolution hypothesis yang dinyatakan oleh Jo \& Harjoto (2011) bahwa perusahaan. mengungkapkan CSR sebagai kegiatan untuk mengurangi agency problem antara 
manajemen dan. berbagai .pihak termasuk shareholder, yang akan berdampak pada meningkatnya nilai perusahaan.

Teori legitimasi menjelaskan bahwa perusahaan mempunyai kontrak dengan masyarakat sekitar yang bertujuan untuk menjalankan kegiatan usahanya (Haniffa \& Cooke, 2005). Pengungkapan CSR perusahaan, dilakukan untuk memperoleh nilai positif serta legitimasi dari masyarakat (Barkemeyer, 2007). Menurut Tarek (2019) Corporate Social .Responsibility adalah suatu komitmen bisnis yang bertindak secara etis, beroperasi secara legal dan berpartisipasi dalam peningkatan perekonomian. Hubungan Corporate Social Responsibility dengan nilai perusahaan juga berkaitan dengan teori sinyal. Dalam teori sinyal dijelaskan bahwa kegiatan sosial dan lingkungan memberikan informasi kepada investor tentang prospek return masa depan substansial. Pengungkapan CSR memberikan sinyal baik yang diberikan oleh manajemen kepada publik bahwa perusahaan memiliki prospek yang baik, yang akan meningkatnya nilai perusahaan (Suwisnaya \& Krisnadewi, 2017). Program CSR digolongkan sebagai investasi jangka panjang, karena CSR adalah salah satu bagian dari strategi bisnis perusahaan, maka dari itu CSR tidak dapat dilihat dalam jangka pendek. Banyak perusahaan telah mengalokasikan sumber daya dan upaya untuk mengungkapkan informasi yang luas tentang aktivitas CSR untuk memastikan bahwa perusahaan sudah menerapkan CSR dengan baik kepada semua pemangku kepentingan perusahaan (Nekhili et al., 2017).

Praktik pengungkapan tanggung jawab sosial di Indonesia diatur oleh Ikatan Akuntansi Indonesia (IAI) dalam Pernyataan Standar Akuntansi Keuangan (PSAK) No. 1 Revisi 2015 pada paragraf 14 dinyatakan bahwa: "Entitas dapat pula menyajikan, terpisah dari laporan keuangan, laporan mengenai lingkungan hidup dan laporan nilai tambah (value added statement), khususnya bagi industri dimana faktor-faktor lingkungan hidup memegang peranan penting dan bagi industri yang menganggap karyawan sebagai kelompok pengguna laporan yang memegang peranan penting. Laporan tambahan tersebut di luar ruang lingkup Standar Akuntansi Keuangan". Dari pernyataan di atas, menjelaskan bahwa perusahaan belum diwajibkan dalam menyampaikan pengungkapan CSR, sehingga dalam prakteknya pengungkapan CSR masih bersifat sukarela (voluntary).

Leverage merupakan sumber dana eksternal karena leverage mewakili. utang yang. dimiliki perusahaan. Jika perusahaan dapat mengelola utang nya dengan baik untuk meningkatkan. keuntungan maka bisa memberikan respon positif bagi investor. Sebaliknya jika perusahaan tidak dapat mengelola utang dengan baik maka bisa memberikan respon negatif bagi investor. Perusahaan yang memiliki tingkat rasio leverage yang tinggi cenderung akan mengurangi biaya-biaya dalam operasionalnya dan kemungkinan perusahaan melakukan pelanggaran perjanjian hutang (Purba \& Yadnya, 2015). Oleh karena itu, perusahaan dengan leverage yang tinggi akan mengurangi pengungkapan CSR agar tidak menjadi sorotan dari para debtholders. Penelitian yang dilakukan oleh Jayanti \& Suputra (2015) memperoleh hasil bahwa leverage berpengaruh. negatif dan tidak signifikan terhadap nilai perusahaan. Penelitian yang dilakukan oleh penelitian Putra \& Budiasih (2017) Kodongo et al., (2014), (Cheryta et al., 2017) yang menyatakan bahwa leverage berpengaruh negatif. dan signifikan pada nilai 
perusahaan. Penelitian Dewi \& Suputra (2018) menunjukkan hasil bahwa CSR. memperlemah pengaruh leverage pada nilai perusahaan, hal ini sejalan dengan penelitian yang dilakukan Wulandari \& Wiksuana (2017).

Pengungkapan CSR, digunakan perusahaan agar memperoleh citra yang baik dari stakeholder. Semakin besar utang, maka semakin besar kemungkinan perusahaan tidak mampu membayar kewajiban berupa pokok beserta bunganya. Dengan begitu investor akan ragu serta akan kehilangan kepercayaannya pada perusahaan, karena banyaknya utang yang dimiliki perusahaan. Hal ini juga berdampak pada menurunnya citra positif yang sudah dibangun perusahaan dengan mengungkapkan CSR. Semakin besar pengungkapan Corporate Social Responsibility yang dilakukan perusahaan namun jika memiliki tingkat leverage yang tinggi akan dapat menurunkan nilai perusahaan. Berdasarkan teori dan hasil penelitian sebelumnya, maka hipotesis yang diajukan dalam penelitian ini adalah:

$\mathrm{H}_{1}$ : Pengungkapan Corporate Social.Responsibility memperlemah pengaruh negatif leverage pada nilai perusahaan.

Kepemilikan Manajerial dalam teori keagenan merupakan salah satu cara yang dapat dilakukan perusahaan dalam usaha mengurangi agency conflict. Masalah keagenan terjadi karena adanya asimetri informasi, dimana pihak manajemen mengetahui lebih banyak informasi mengenai perusahaan dibandingkan prinsipal. Upaya perusahaan untuk mengurangi agency conflict yaitu dengan kepemilikan manajerial yang secara tidak. langsung dapat berdampak pada meningkatnya nilai perusahaan, karena dengan adanya proporsi kepemilikan saham manajemen dapat menciptakan keselarasan kepentingan antara manajer dengan pemegang saham. Pengungkapan CSR yang dilakukan perusahaan merupakan cara untuk menggambarkan bahwa perusahaan yang memiliki kepemilikan manajerial tinggi lebih mengutamakan image atau citra baik perusahaan di mata investor karena manajer sendiri yang melakukan pengelolaan perusahaan. Semakin baik citra perusahaan, maka semakin meningkat minat investor untuk berinvestasi pada perusahaan dan akan membuat nilai perusahaan mengalami peningkatan.

Menurut teori agensi, pengungkapan CSR yang dilakukan. perusahaan juga dapat mengurangi adanya asimetri informasi, dengan transparansi yang ditingkatkan melalui pelaporan non keuangan. Dengan adanya pengungkapan Corporate Social Responsibility dapat memberikan sinyal .positif tentang pertumbuhan perusahaan di masa yang akan datang, sehingga dapat meningkatkan nilai perusahaan. Hal ini sesuai dengan penelitian yang dilakukan Anita \& Yulianto (2014), Hatem (2015) menemukan pengaruh positif dan signifikan antara kepemilikan manajerial terhadap nilai perusahaan. Hal ini searah dengan penelitian yang dilakukan Rachman (2012) menyatakan bahwa dengan meningkatnya kepemilikan manajerial akan memberikan dampak positif pada nilai perusahaan. Penelitian Ratih \& Damayanthi (2016), menyatakan bahwa pengungkapan Corporate Social Responsibility sebagai variabel pemoderasi yang memperkuat pengaruh kepemilikan manajerial pada nilai perusahaan. Hasil penelitian ini sejalan dengan penelitian yang dilakukan oleh Widyaningsih (2018). 
Dari penelitian-penelitian tersebut dapat dilihat bahwa CSR dapat mempengaruhi hubungan kepemilikan manajerial pada nilai perusahaan. Dengan nilai perusahaan yang baik, maka akan menarik minat para investor dalam berinvestasi. Kepedulian perusahaan dalam menjaga lingkungan sekitar perusahaan membuat masyarakat maupun investor akan lebih percaya pada keberlanjutan perusahaan dan akan membuat nilai perusahaan terlihat lebih baik. Akan tetapi, investor tidak ingin berisiko dalam menanamkan modalnya di suatu perusahaan, mereka lebih cenderung memilih perusahaan yang telah mengungkapkan tanggung jawab sosial dalam laporan tahunan. Perusahaan dengan kepemilikan manajerial tinggi cenderung akan meningkatkan nilai perusahaaan dengan pengungkapan CSR. Semakin .besar pengungkapan CSR yang dilakukan perusahaan, maka pengaruh kepemilikan manajerial pada nilai perusahaan akan semakin meningkat. Berdasarkan teori dan hasil penelitian sebelumnya, maka hipotesis yang diajukan dalam penelitian ini adalah:

$\mathrm{H}_{2}$ : Pengungkapan Corporate .Social .Responsibility memperkuat pengaruh positif kepemilikan manajerial pada nilai perusahaan.

\section{METODE PENELITIAN}

Lokasi penelitian ini dilakukan pada perusahaan pertambangan yang terdaftar di BEI tahun 2014-2018. Jenis data dalam penelitian ini adalah data kuantitatif yaitu laporan tahunan (annual report) perusahaan pertambangan. Sumber data. sekunder penelitian ini diperoleh melalui BEI periode 2014-2018, Jurnal, makalah, penelitian, buku referensi dan situs resmi perusahaan yang diteliti. Sampel penelitian adalah perusahaan pertambangan yang dipilih menggunakan metode nonprobability sampling dengan teknik purposive. sampling di Bursa Efek Indonesia periode 2014 - 2018. Metode pengumpulan data yang digunakan dalam penelitian ini adalah metode dokumentasi. Dalam penelitian ini metode dokumentasi dilakukan dengan cara memperoleh data menggunakan dokumentasi yang berdasarkan pada laporan keuangan dan laporan tahunan perusahaan yang dipublikasikan oleh BEI ataupun pada web resmi perusahaan itu sendiri. Variabel-varibel penelitian ini yaitu variabel bebas adalah leverage $\left(\mathrm{X}_{1}\right)$, kepemilikan manajerial $\left(\mathrm{X}_{2}\right)$. Variabel terikat adalah nilai perusahaan $(\mathrm{Y})$. Variabel moderasi adalah pengungkapan CSR (Z).

Besaran leverage didapatkan dari annual report perusahaan pertambangan. Rumus untuk menghitung Debt to Equity Ratio (DER) yaitu (Husnan dan Pudjiastuti, 2004:70).

$$
\text { DER }=\frac{\text { Total Hutang }}{\text { Total Ekwitas }} \times 100 \%
$$

Kepemilikan manajerial adalah pemegang saham dari pihak manajemen yang secara aktif ikut dalam pengambilan keputusan perusahaan. Kepemilikan manajerial dihitung dengan rumus (Putri dan Bambang, 2016).

Jumlah sahamyang dimiliki manajemen

$\mathrm{KM}=$ jumlahsahamyang beredar $\times 100 \%$

Penelitian ini menggunakan rasio Tobin's $Q$, karena rasio ini dipercaya dapat memberikan informasi yang paling baik dibandingkan alat ukur nilai perusahaan lainnya (Fajriana, 2016). Rumus Tobin's Q dalam penelitian ini adalah sebagai berikut (Hartoyo, 2016): 
Tobin's $Q=\frac{\text { MVE }+ \text { DEBT }}{T A}$

Keterangan :

Tobin's Q = Nilai Perusahaan $(Y)$

MVE = Market Value of Equity / nilai pasar ekuitas saham

DEBT $=$ Total utang perusahaan

TA $\quad=$ Total aktiva

Pengungkapan CSR menggunakan pedoman ISO 26000, dengan demikian akan memudahkan perusahaan dalam menetapkan kriteria pengungkapan CSR. Berdasarkan penjabaran indikator ISO 26000 terdapat 37 item Corporate Social Responsibility Disclosure. Pedoman ISO 26000 mengukur intensitas CSR yang dapat dilihat di annual report. Pengukuran ISO 26000 menggunakan variabel dummy, dimana jika perusahaan mengungkapkan item pengungkapan CSR dalam laporan tahunan makan diberi skor 1 (satu), namun jika perusahaan tidak mengungkapkan item pengungkapan CSR dalam laporan tahunan maka diberi skor 0 (nol). Rumus pengukurannya yaitu: (Kusumawardani, 2017).

CSRDI $=\frac{\text { Jumlah item informasi CSR yang diungkapkan }}{\text { Jumlah item informasi CSR menurut ISO } 26000}$

Pengujian Moderated Regression Analysis (MRA) dipilih dalam penelitian ini dikarenakan MRA dapat menjelaskan pengaruh variabel pemoderasi dalam memperkuat maupun memperlemah pengaruh variabel independen pada variabel dependennya. Model regresi moderasi dalam penelitian ini ditunjukkan oleh persamaan berikut:

$Y=\alpha+\beta_{1} X_{1}+\beta_{2} X_{2}+\beta_{3} Z+\beta_{4} X_{1} \cdot Z+\beta_{5} X_{2} \cdot Z+e$

Keterangan :

$\mathrm{Y}=$ Nilai Perusahaan

$\mathrm{a} \quad=$ Konstanta

$\mathrm{X}_{1}=$ Leverage

$\mathrm{X}_{2} \quad=$ Kepemilikan Manajerial

$\mathrm{Z}=$ Pengungkapan CSR

$\mathrm{X}_{1} \cdot \mathrm{Z}=$ Interaksi antara leverage dan Pengungkapan CSR

$\mathrm{X}_{2} . \mathrm{Z}=$ Interaksi antara kepemilikan manajerial dan Pengungkapan CSR

$\beta_{1-} \beta_{5}=$ Koefisien Regresi

e $\quad=$ Standar error

\section{HASIL DAN PEMBAHASAN}

Penelitian ini dilakukan pada Perusahaan pertambangan yang terdaftar di BEI periode 2014-2018. Sektor pertambangan merupakan salah satu penopang pembangunan ekonomi suatu negara, karena perannya sebagai penyedia sumber daya energi yang sangat diperlukan bagi pertumbuhan perekonomian suatu negara. Perusahaan Pertambangan merupakan salah satu sektor industri yang terdaftar di BEI. Perusahaan Pertambangan yang terdaftar di BEI terbagi menjadi beberapa sub sektor yaitu sub sektor batubara, minyak dan gas bumi, logam dan mineral serta sub sektor tanah dan batu galian. Hasil analisis sampel dengan menggunakan purposive sampling disajikan pada Tabel 1 . 
Tabel 1. Proses Seleksi Sampel dengan purposive sampling

\begin{tabular}{lll}
\hline No & Populasi & Jumlah \\
\hline & $\begin{array}{l}\text { Perusahaan Pertambangan yang terdaftar di Bursa Efek Indonesia } \\
\text { periode 2014-2018 }\end{array}$ & 49 \\
& $\begin{array}{l}\text { Kriteria } \\
1\end{array}$ & $\begin{array}{l}\text { Perusahaan Pertambangan yang tidak mempublikasikan annual } \\
\text { report secara berturut-turut selama tahun 2014-2018 }\end{array}$ \\
2 & $\begin{array}{l}\text { Perusahaan pertambangan yang tidak menyajikan pengungkapan } \\
\text { CSR pada laporan tahunan selama periode tahun 2014-2018 }\end{array}$ & $(2)$ \\
3 & $\begin{array}{l}\text { Perusahaan pertambangan yang memiliki proporsi kepemilikan } \\
\text { manajerial selama periode tahun 2014-2018 }\end{array}$ & $(21)$ \\
Jumlah perusahaan yang digunakan sebagai sampel & 13 \\
Jumlah pengamatan penelitian selama tahun 2014-2018 & 65 \\
\hline
\end{tabular}

Sumber: Data Penelitian, 2019

Berdasarkan hasil seleksi sampel dengan purposive sampling diperoleh 13 perusahaan sebagai sampel penelitian akibat dari tidak semua perusahaan memiliki kepemilikan manajemen dalam suatu annual report perusahaan. Sesuai dengan kriteria pemilihan sampel maka diperoleh sampel dengan jumlah 65 sampel.

Statistik deskriptif disajikan untuk menyajikan informasi mengenai karakteristik variabel. penelitian, yaitu jumlah sampel, nilai maksimum, nilai minimum, nilai rata-rata dan standar deviasi. Hasil uji statistik deskriptif dapat dilihat pada Tabel 2 berikut.

\section{Tabel 2. Hasil Uji Statistik Deskriptif}

\begin{tabular}{llllll}
\hline & $\mathrm{N}$ & Minimum & Maximum & Mean & Std. Deviation \\
\hline Leverage & 65 &, 108390 & 9,31075 & 1,701725 & 2,190970 \\
Kepemilikan Manajerial & 65 &, 000002 &, 662935 &, 097169 &, 189778 \\
CSRD & 65 &, 243243 &, 594594 &, 397921 &, 082685 \\
Tobins Q & 65 &, 102585 & 3,719057 &, 859584 &, 591340 \\
Valid N (listwise) & 65 & & & & \\
\hline
\end{tabular}

Sumber: Data Penelitian, 2019

Berdasarkan uji statistik deskriptif, variabel leverage memiliki nilai minimum sebesar 0,108390. Nilai maksimum leverage adalah sebesar 9,31075. Mean (rata-rata) dari leverage adalah 1,701725. Standar deviasi sebesar 2,190970. Variabel kepemilikan manajerial memiliki nilai minimum sebesar 0,000002. Nilai maksimum variabel kepemilikan manajerial sebesar 0,662935. Variabel kepemilikan manajerial cenderung rendah dilihat dari rata-ratanya yaitu sebesar 0,097169 atau sebesar 9,72 \%. Standar deviasi sebesar 0,189778 atau sebesar 18,97 $\%$. Variabel pengungkapan CSR memiliki nilai minimum adalah sebesar 0,243243. Nilai Maksimum pengungkapan CSR adalah sebesar 0,594594. Mean (rata-rata) dari pengungkapan CSR adalah 0,397921 dengan standar deviasi sebesar 0,082685. Variabel nilai perusahaan memiliki nilai minimum sebesar 0,102585 . Nilai maksimum adalah sebesar 3.719057. Mean (rata-rata) dari nilai perusahaan adalah sebesar 0,859584. Standar deviasi sebesar 0.591340 . 
Tabel 3. Hasil Uji Normalitas

\begin{tabular}{lll}
\hline & & Unstandardized Residual \\
\hline $\mathrm{N}$ & & 65 \\
Normal Parametersa,b & Mean &, 0000000 \\
& Std. Deviation &, 59065019 \\
Most Extreme Differences & Absolute &, 128 \\
& Positive &, 128 \\
& Negative &,- 079 \\
Kolmogorov-Smirnov Z & & 1,032 \\
Asymp. Sig. (2-tailed) & &, 238 \\
\hline
\end{tabular}

Sumber: Data Penelitian, 2019

Berdasarkan hasil analisis pada Tabel 3. menunjukkan bahwa nilai signifikansi sebesar 0,238 lebih besar dari 0,05 sehingga dapat disimpulkan bahwa variabel yang digunakan dalam penelitian ini berdistribusi normal.

Tabel 4. Hasil Uji Multikolinearitas

\begin{tabular}{lll}
\hline Model & \multicolumn{2}{l}{ Collinearity Statistics } \\
\cline { 2 - 3 } & Tolerance & VIF \\
\hline (Constant) & & \\
Leverage & 0,933 & 1,072 \\
Kepemilikan Manajerial & 0,945 & 1,058 \\
CSRD & 0,981 & 1,020 \\
\hline
\end{tabular}

Sumber: Data Penelitian, 2019

Setelah melakukan uji multikolinearitas, dimana diperlihatkan bahwa seluruh variabel memiliki nilai Tolerance yang lebih besar dari 0,10 dan nilai VIF yang lebih kecil dari 10. Oleh karena itu berdasarkan nilai Tolerance dan VIF pada model analisis tersebut tidak ditemukan adanya gejala multikolinearitas.

Tabel 5. Hasil Uji Autokorelasi

\begin{tabular}{|c|c|c|c|c|c|}
\hline Model & R Square & $\begin{array}{l}\text { Adjuste } \\
\text { Square }\end{array}$ & $\begin{array}{l}\text { RStd. Errol } \\
\text { Estimate }\end{array}$ & of the & atson \\
\hline dimension $0_{1}$ & $0,661^{a}$ & 0,437 & 0,389 & 0,61516884 & 2,192 \\
\hline
\end{tabular}

Sumber: Data Penelitian, 2019

Hasil uji autokorelasi yang diperoleh adalah 1,767 $<2,192<2,233$, maka dapat disimpulkan bahwa model regresi dengan uji durbin watson memenuhi kriteria $\mathrm{d} U<\mathrm{dW}<4-\mathrm{dU}$ yang berarti bahwa tidak ada autokorelasi antar nilai residual.

Tabel 6. Hasil Uji Heteroskedastisitas

\begin{tabular}{|c|c|c|c|c|c|c|}
\hline \multirow{2}{*}{\multicolumn{2}{|c|}{ Model }} & \multicolumn{2}{|c|}{ Unstandardized Coefficients } & $\begin{array}{l}\text { Standardized } \\
\text { Coefficients }\end{array}$ & \multirow[b]{2}{*}{$\mathrm{T}$} & \multirow[b]{2}{*}{ Sig. } \\
\hline & & $\bar{B}$ & Std. Error & Beta & & \\
\hline \multirow[t]{7}{*}{1} & (Constant) & 0,422 & 0,049 & & 8,676 & 0,000 \\
\hline & Leverage & $-0,048$ & 0,214 & $-0,122$ & $-0,223$ & 0,824 \\
\hline & Kepemilikan & 0,105 & 0,075 & 0,188 & 1,411 & 0,164 \\
\hline & Manajerial & & & & & \\
\hline & CSRDI & 0,102 & 0,055 & 0,260 & 1,844 & 0,070 \\
\hline & Interaksi $X_{1} . Z$ & $-0,069$ & 0,051 & $-0,176$ & $-1,340$ & 0,185 \\
\hline & Interaksi $X_{2} . Z$ & 0,110 & 0,235 & 0,258 & 0,467 & 0,642 \\
\hline
\end{tabular}

Sumber: Data Penelitian, 2019 
Berdasarkan Tabel 6 maka dapat disimpulkan bahwa nilai signifikansi keseluruhan nilai variabel bebas berada pada tingkat signifikansi $>0.05$. Hasil uji menunjukkan bahwa memiliki nilai lebih besar dari $a=0.05$. Maka dapat disimpulkan tidak terjadi heteroskedastisitas.

Tabel 7. Hasil Uji Moderated Regression Analysis (MRA)

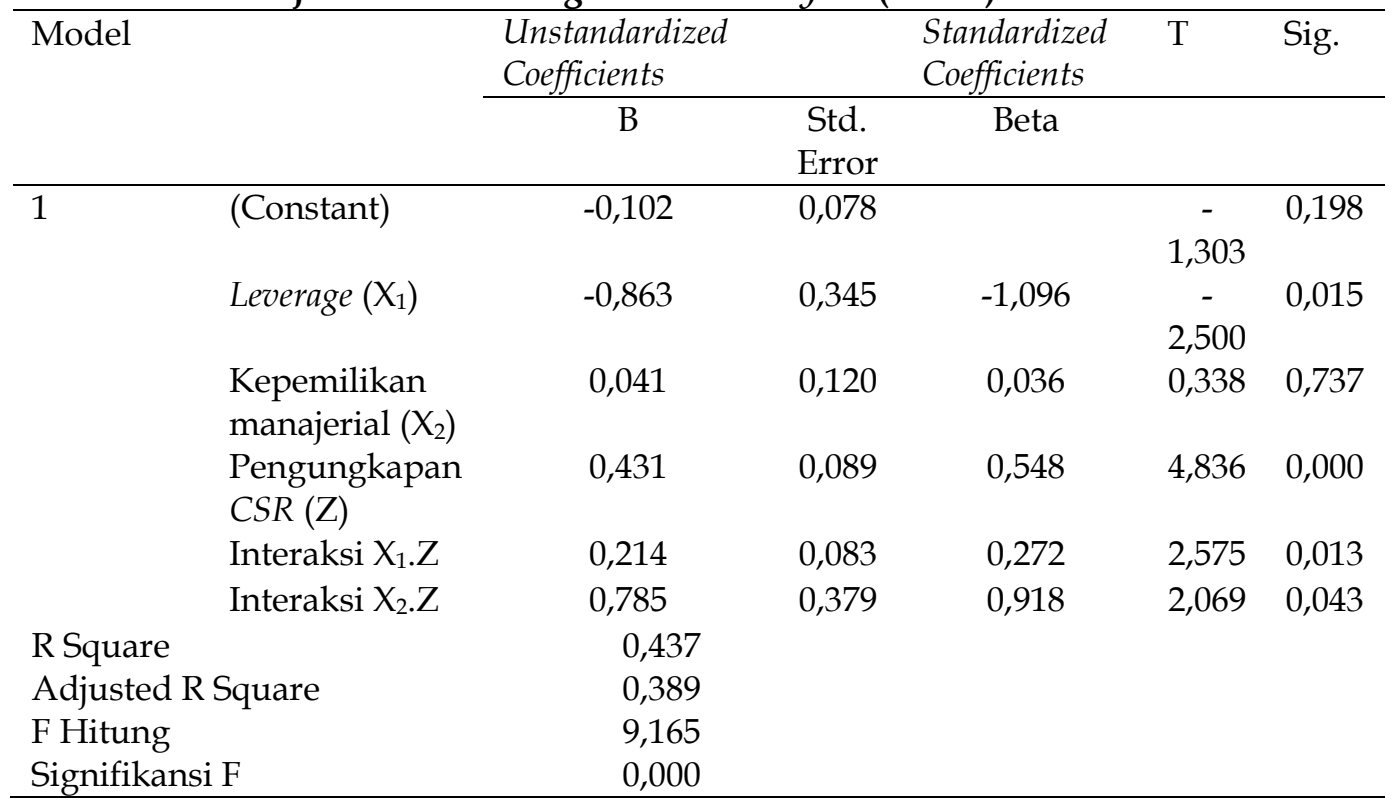

Sumber: Data Penelitian, 2019

Berdasarkan hasil analisis MRA seperti yang disajikan pada Tabel 7, maka persamaan struktural yang dapat dibentuk adalah sebagai berikut:

$$
Y=-0,102-0,863 X_{1}+0,041 X_{2}+0,431 Z+0,214 X_{1} \cdot Z+0,785 X_{2} \cdot Z+e
$$

Koefisien determinasi $\left(\mathrm{R}^{2}\right)$ digunakan untuk mengetahui dan mengukur kemampuan model dalam menerangkan variasi variabel dependen. Hasil pengujian ini diperoleh besarnya adjusted $\mathrm{R}^{2}$ adalah sebesar 0,389 . Ini berarti variasi nilai perusahaan dapat dipengaruhi secara signifikan oleh variabel Leverage, kepemilikan manajerial, pengungkapan CSR, serta Interaksi antara leverage dan kepemilikan manajerial dengan pengungkapan CSR sebesar 38,9 persen sedangkan sisanya 61,1 persen dijelaskan oleh faktor lain yang tidak dijelaskan dalam penelitian.

Uji kelayakan model (Uji F) digunakan untuk mengetahui apakah model Moderated Regression Analysis (MRA) dalam penelitian ini layak untuk digunakan. Berdasarkan Tabel 7, menunjukkan hasil bahwa bahwa nilai signifikansi $\mathrm{P}$ value 0,000 yang lebih kecil dari $a=0,05$, ini berarti model yang digunakan pada penelitian ini adalah layak. Hasil ini memberikan makna bahwa seluruh variabel independen yaitu leverage, kepemilikan manajerial, dan variabel interaksi antara leverage dan kepemilikan manajerial dengan pengungkapan CSR mampu memprediksi atau menjelaskan fenomena nilai perusahaan pertambangan yang terdaftar di Bursa Efek Indonesia tahun 2014-2018.

Hipotesis pertama dalam penelitian ini menyatakan bahwa pengungkapan CSR memperlemah pengaruh leverage pada nilai perusahaan. Berdasarkan hasil pengujian dengan menggunakan MRA pada Tabel 7, variabel leverage berpengaruh negatif dan signifikan pada nilai perusahaan. Penelitian ini 
menambahkan variabel Pengungkapan Corporate Social Responsibility sebagai variabel pemoderasi. Sebelum ditambahkan variabel moderasi, leverage memiliki pengaruh negatif dan signifikan pada nilai perusahaan dan setelah ditambahkan variabel pemoderasi leverage memiliki pengaruh positif dan signifikan pada nilai perusahaan. Hal ini menunjukkan bahwa koefisien regresi variabel interaksi antara leverage dengan Pengungkapan CSR menunjukkan nilai koefisien yang berbeda sehingga menunjukkan hubungan. yang berlawanan atau tidak searah, maka dapat disimpulkan bahwa variabel pengungkapan Corporate Social Responsibility merupakan variabel. moderasi yang memperlemah pengaruh. leverage pada nilai perusahaan.

Hal ini membuktikan adanya peningkatan utang dapat. diartikan oleh pihak luar mengenai. kemampuan perusahaan dalam membayar keawajibannya di masa mendatang atau adanya risiko bisnis yang tinggi, hal ini dapat direspon negatif oleh pasar serta akan mencerminkan citra yang kurang baik dari investor kepada perusahaan. Hasil penelitian ini didukung oleh penelitian yang dilakukan (Putra \& Budiasih, 2017) (Kodongo et al., 2014) yang menyatakan bahwa leverage berpengaruh negatif dan signifikan pada nilai perusahaan, yang berarti semakin tinggi leverage maka semakin rendah nilai perusahaannya. Semakin tinggi tingkat leverage, maka semakin besar peluang perusahaan melanggar perjanjian utang, sehingga perusahaan akan melaporkan laba sekarang lebih tinggi dibandingkan laba di masa depan. Dengan laba yang dilaporkan tinggi membuat manajer harus mengurangi biaya atau pengeluaran, termasuk biaya atau pengeluaran untuk mengungkapkan tanggung jawab sosial (Anugerah et al., 2010). Menurut (Belkaoui \& Karpik, 1989), keputusan untuk mengungkapkan CSR akan diikuti oleh suatu pengeluaran untuk pengungkapan yang akan berdampak pada menurunnya pendapatan.

Menurut Agency theory, manajemen perusahaan dengan tingkat leverage yang tinggi akan mengurangi pengungkapan CSR yang dibuatnya agar tidak menjadi sorotan dari para debtholder yang akan berdampak pada nilai perusahaan. Menurut Friedman (1970) dalam Chang (2014) menyatakan bahwa penggunaan utang yang tinggi dengan. diimbangi pelaksanaan CSR yang tinggi tidak mampu mengurangi. daya saing perusahaan sehingga akan berdampak pada turunnya nilai perusahaan. Hasil penelitian ini sejalan dengan penelitian yang .dilakukan oleh Dewi \& Suputra, (2018), Wulandari \& Wiksuana (2017) serta Jayanti \& Suputra (2015) memperoleh hasil bahwa pengungkapan CSR sebagai variabel moderasi yang memperlemah pengaruh leverage pada nilai perusahaan. Hal ini menjelaskan bahwa perusahaan yang memiliki leverage yang tinggi namun jika pengungkapan CSR nya tinggi akan menurunkan nilai perusahaan. Hal ini berarti bahwa semakin besar pengungkapan Corporate Social Responsibility yang dilakukan perusahaan, menyebabkan semakin lemah hubungan leverage pada nilai perusahaan.

Hipotesis kedua dalam penelitian ini menyatakan bahwa pengungkapan Corporate Social Responsibility memperkuat pengaruh kepemilikan manajerial pada nilai. perusahaan. Berdasarkan Berdasarkan hasil pengujian dengan menggunakan MRA pada Tabel 7, variabel kepemilikan manajerial berpengaruh positif dan tidak signifikan pada nilai perusahaan, sehingga pada penelitian ini menambahkan pengungkapan CSR sebagai variabel moderasi. Walaupun 
sebelum dimoderasi nilai perusahaan tidak dipengaruhi oleh kepemilikan manajerial namun setelah dimoderasi, variabel pengungkapan CSR mampu memperkuat pengaruh kepemilikan manajerial pada nilai perusahaan dari yang tidak signifikan menjadi signifikan. Hal ini menunjukkan adanya hubungan yang searah, karena sama-sama memiliki nilai koefisien yang positif, sehingga dapat disimpulkan bahwa variabel pengungkapan Corporate Social Responsibility merupakan variabel moderasi yang memperkuat pengaruh kepemilikan manajerial pada nilai perusahaan.

Penelitian Ramadhani (2012) menunjukkan perusahaan dengan kepemilikan manajerial yang tinggi cenderung akan meningkatkan nilai perusahaan melalui pengungkapan CSR yang dilakukan perusahaan. Hal ini dilakukan manajer supaya image perusahaan tetap optimal. Dengan optimalnya image perusahaan, membuat manajer semakin produktif dalam memaksimalkan nilai perusahaan. Hasil penelitian ini membuktikan teori agensi bahwa dengan adanya kepemilikan manajerial yang tinggi dan dengan pengungkapan CSR yang tinggi dapat mengurangi asimetri informasi sehingga dapat mereduksi adanya agency cost yang berpotensi timbul. Hasil penelitian ini sesuai dengan penelitian yang dilakukan oleh Hartana \& Putra (2017), Ratih \& Damayanthi (2016) yang menyatakan bahwa pengungkapan CSR variabel moderasi yang memperkuat pengaruh kepemilikan manajerial pada nilai perusahaan. Hal ini menjelaskan bahwa, semakin besar pengungkapan CSR yang dilakukan perusahaan akan memperkuat hubungan kepemilikan manajerial pada nilai perusahaan.

\section{SIMPULAN}

Hasil penelitian ini menunjukkan bahwa Pengungkapan CSR sebagai .variabel moderasi yang memperlemah pengaruh leverage pada nilai perusahaan. Pengungkapan CSR sebagai variabel moderasi yang memperkuat pengaruh kepemilikan manajerial pada nilai perusahaan. Saran dalam penelitian ini yaitu bagi perusahaan pertambangan diharapkan untuk meningkatkan penerapan pengungkapan CSR, karena pengungkapan CSR tidak hanya sebuah pertanggungjawaban perusahaan terhadap lingkungan dan. masyarakat namun jika dilakukan secara maksimal dapat memberikan keuntungan jangka panjang bagi perusahaan. Perusahaan harus mempertimbangkan dengan baik mengenai penggunaan leverage, karena penggunaan utang dapat menimbulkan beban dan risiko terhadap perusahaan jika perusahaan berada pada kondisi yang buruk. Bagi investor dalam pengambilan keputusan untuk berinvestasi, sebaiknya tidak terpaku pada informasi keuangan saja, namun juga tetap memperhatikan aspek non keuangan yaitu pengungkapan CSR yang dilakukan oleh perusahaan.

\section{REFERENSI}

Anita, A., \& Yulianto, A. (2014). Pengaruh Kepemilikan Manajerial dan Kebijakan Dividen Terhadap Nilai Perusahaan. Management Analysis Journal, 15(4), 229-232.

Anugerah, R., Hutabarat, R., \& Faradilla, W. (2010). Pengaruh Ukuran Perusahaan, Leverage Dan Profitabilitas Terhadap Pengungkapan 
Tanggung Jawab Sosial Perusahaan Pada Perusahaan Manufaktur Yang Listing Di BEI. Jumal Ekonomi Volume, 18(1), 118-131.

Astriani, E. F. (2014). Pengaruh Kepemilikan Manajerial, Leverage, Profitabilitas, Ukuran Perusahaan Dan Investment Oppo. Telematics and Informatics, 19(1), 27-40. https:/ / doi.org/10.1177/1742766510373715

Barkemeyer, R. (2007). Legitimacy as a Key Driver and Determinant of CSR in Developing Countries. System, 44(June), 1-23.

Belkaoui, A., \& Karpik, P. G. (1989). Determinants of The Corporate Decision to Disclose Social Information. Accounting, Auditing and Accountability Journal.

Boučková, M. (2015). Management Accounting and Agency Theory. Procedia Economics and Finance, 25(15), 5-13. https://doi.org/10.1016/s22125671(15)00707-8

Chang, Y., \& Shen, C.-H. (2014). Corporate Social Responsibility and Profitability - Cost of Debt as the Mediator. Taipei Economic Inquir, 50(2), 291-357.

Cheryta, A. M., Moeljadi, \& Indrawati, N. K. (2017). The Effect of Leverage, Profitability, Information Asymmetry, Firm Size on Cash Holding and Firm Value of Manufacturing Firms Listed at Indonesian Stock Exchange. International Journal of Research in Business Studies and Management, 4(4), 21-31. https:// doi.org/10.22259/ijrbsm.0404004

Dewi, N. M. L., \& Suputra, I. D. G. D. (2019). Pengaruh Profitabilitas dan Leverage pada Nilai Perusahaan dengan Corporate Social Responsibility Sebagai Variabel Pemoderasi. E-Jurnal Akuntansi Universitas Udayana, 28, 26-54.

Fajriana, A. (2016). Pengaruh Corporate Social Responsibility, Keputusan Investasi, Dan Struktur Modal Terhadap Nilai Perusahaan. Nominal, Barometer Riset Akuntansi Dan Manajemen, 5(2). https://doi.org/10.21831/nominal.v5i2.11721

Fama, E. F., \& French, K. R. (2007). Taxes, Financing Decisions, and Firm Value. The Journal of Finance. 53(3), 819-843.

Govindarajan, V. (1986). Impact of Participation in the Budgetary Process on Managerial Attitudes and Performance: Universalistic and Contingency Perspectives. Decision Sciences, 17(4), 496-516. https://doi.org/10.1111/j.1540-5915.1986.tb00240.x

Haniffa, R. M., \& Cooke, T. E. (2005). The impact of culture and governance on corporate social reporting. Journal of Accounting and Public Policy, 24(5), 391-430. https://doi.org/10.1016/j.jaccpubpol.2005.06.001

Hargiansyah, R. F. (2015). Pengaruh Ukuran Perusahaan, Leverage dan Profitabilitas terhadap Nilai Perusahaan (Studi Empiris pada Perusahaan Manufaktur yang Terdaftar di Bursa Efek Indonesia). Artikel Ilmiah Akuntansi Fakultas Ekonomi UNEJ.

Hartana, I. B. P. R., \& Putra, N. W. A. (2017). Pengaruh Kepemilikan Manajerial dan Kepemilikan Institusional Pada Nilai Perusahaan Dengan Corporate Social Responsibility Sebagai Pemoderasi. E-Jurnal Akuntansi Universitas Udayana, 21(3), 1903-1932.

Hartoyo. (2016). Analisis Pengaruh Profitabilitas, Pengungkapan Corporate Social Responsibility Dan Corporate Governance Terhadap Nilai 
Perusahaan. Skripsi Sarjana Jurusan Akuntansi Fakultas Ekonomi Dan Bisnis Universitas Muhammadiyah, Surakarta, 147, 11-40.

Hatem, B. S. (2015). Interdependence between Managerial Ownership, Leverage and Firm Value: Theory and Empirical Validation. International Journal of $\begin{array}{llll}\text { Economics and } & \text { Finance, }\end{array}$ https://doi.org/10.5539/ijef.v7n12p106

Hidayah, N. (2015). Pengaruh Investment Opportunity Set (Ios) Dan Kepemilikan Manajerial Terhadap Nilai Perusahaan Pada Perusahaan Property Dan Real Estat Di Bursa Efek Indonesia. Jurnal Akuntansi, 19(3), 420. https:// doi.org/10.24912/ja.v19i3.89

Husnan, S., \& Pudjiastuti, E. (2004). Dasar-Dasar Manajemen Keuangan (Keempat). Yogyakarta: UPP AMP YKPN.

Indasari, A. P., \& Yadnyana, I. K. (2018). Pengaruh Profitabilitas, Growth Opportunity, Likuiditas, dan Struktur Modal Pada Nilai Perusahaan. EJurnal Akuntansi, 22, 714. https:// doi.org/10.24843/EJA.2018.v22.i01.p27

Jayanti, A. A. S. P., \& Suputra, I. D. G. D. (2015). Kemampuan Corporate Social Responsibility (CSR) Memoderasi Pengaruh Good Corporate Governance (GCG) dan Leverage Pada Nilai Perusahaan. E-Jurnal Akuntansi Universitas Udayana, 14(1), 118-143.

Jo, H., \& Harjoto, M. A. (2011). Corporate Governance and Firm Value: The Impact of Corporate Social Responsibility. Journal of Business Ethics, 103(3), 351-383. https://doi.org/10.1007/s10551-011-0869-y

Kalay, A. (1982). Stockholder-Bondholder Conflict and Dividend Constraints. Journal of Financial Economics, 10(2), 211-233.

Kodongo, O., Mokoteli, M. T., \& Maina, L. (2014). Capital structure, profitability and Firm Value: panel evidence of listed firms in Keny. Munich Personal RePEc Archive, (2116), 0-33. https://doi.org/10.1227/01.NEU.0000349921.14519.2A

Kusumawardani, I. (2017). Faktor-Faktor Yang Memengaruhi Pengungkapan Corporate Social Responsibility. E-Jurnal Akuntansi Universitas Udayana, 19(1), 741-770.

Mandey, S., Pangemanan, S., \& Pangerapan, S. (2017). Analisis Pengaruh Insider Ownership, Leverage, Dan Profitabilitas Terhadap Nilai Perusahaan Pada Sektor Perusahaan Manufaktur Di Bursa Efek Indonesia Periode Tahun 2013-2015. Jurnal Riset Ekonomi, Manajemen, Bisnis Dan Akuntansi, 5(2), 1463-1473.

Nekhili, M., Nagati, H., Chtioui, T., \& Rebolledo, C. (2017). Corporate social responsibility disclosure and market value: Family versus nonfamily firms. Journal of Business Research, 77(July 2016), 41-52. https://doi.org/10.1016/j.jbusres.2017.04.001

Pratama, I. G. B. A., \& Wiksuana, I. G. B. (2016). Pengaruh Ukuran Perusahaan Dan Leverage Terhadap Nilai Perusahaan Dengan Profitabilitas Sebagai Variabel Mediasi. E-Jurnal Manajemen Unud, 5(2), 1338-1367.

Purba, I. B. I. W., \& Yadnya, P. (2015). Pengaruh Ukuran Perusahaan Dan Leverage Terhadap Profitabilitas Dan Pengungkapan Corporate Social Responsibility. E-Jurnal Akuntansi Universitas Udayana, 4(8), 2428-2443. 
Putra, I. P. D. P., \& Budiasih, I. G. A. N. (2017). Pengaruh Karakteristik Perusahaan dan Kepemilikan Institusional Pada Nilai Perusahaan dengan CSR sebagai Variabel Intervening. E-Jurnal Akuntansi, 21, 12631289. https://doi.org/10.24843/EJA.2017.v21.i02.p15

Putri, I. A. S., \& Bambang, S. H. (2016). Pengaruh Tanggung Jawab Sosial Perusahaan Dan Mekanisme Tata Kelola Perusahaan Terhadap Nilai Perusahaan. E-Jurnal Akuntansi Universitas Udayana, 15(1), 667-694.

Rachman, A. A. (2012). Pengaruh Corporate Social Responsibility (Csr), Kepemilikan Manajerial Dan Institusional Terhadap Nilai Perusahaan. Jurnal Sekolah Tinggi Ilmu Ekonomi Perbanas, 114-119.

Ramadhani, L. S., \& Basuki, H. (2012). Pengaruh Corporate Social Responsibility Terhadap Nilai Perusahaan Dengan Prosentase Kepemilikan Manajemen Sebagai Variabel Moderating Pada Perusahaan Manufaktur yang Terdaftar di BEI. Jurnal Akuntansi Dan Auditing, 8(2), 95-185.

Ratih, I., \& Damayanthi, I. E. (2016). Kepemilikan Manajerial Dan Profitabilitas Pada Nilai Perusahaan Dengan Pengungkapan Tanggungjawab Sosial Sebagai Variabel Pemoderasi. E-Jurnal Akuntansi Universitas Udayana, 14(2), 1510-1538.

Rini, I. S., T, S., \& Nurkholis. (2017). The Effect of Ownership Structure on Firm value With Investment Decision As Intervening Variable (Empirical study of The Listed Companies In Indonesia stock Exchange 2014). International Journal of Social and Local Economic Governance (IJLEG), 3(2), 99-110.

Suwisnaya, I. P. P., \& Krisnadewi, K. A. (2017). Pengaruh Kebijakan Utang Pada Nilai Perusahaan Dengan Ukuran Perusahaan Sebagai Variabel Moderasi. Jurnal Ilmiah Wahana Akuntansi, 12(1), 1. https://doi.org/10.21009/wahana.012/1.1

Tarek, Y. (2019). The Impact of Financial Leverage and CSR on the Corporate Value: Egyptian Case. International Journal of Economics and Finance, 11(4), 74. https:// doi.org/10.5539/ijef.v11n4p74

Tristiarini, N. (2014). Peran Agency Cost Reduction, Kualitas Tata Kelola Perusahaan dan Risiko Pasar dalam Hubungan Corporate Social Responsibility dan Nilai Perusahaan. Disertasi. Universitas Dian Nuswantoro., 1-8. Retrieved from http://journal.feb.unmul.ac.id

Wiagustini, N, L, P. (2010). Manajemen Keuangan. Denpasar: Udayana University Press.

Widyaningsih, D. (2018). Kepemilikan Manajerial, Kepemilikan Institusional, Komisaris Independen, serta Komite Audit pada Nilai Perusahaan dengan Pengungkapan CSR sebagai Variabel Moderating dan Firm Size sebagai Variabel Kontrol. Jurnal Akuntansi Dan Pajak, 19(1), 38. https://doi.org/10.29040/jap.v19i1.196

Wulandari, N. M. . I., \& Wiksuana, I. G. B. (2017). Peranan Corporate Social Responsibility Dalam Memoderasi pengaruh profitabilitas, Leverage, Dan, ukuran Perusahaan Terhadap Nilai Perusahaan. E-Jurnal Manajemen, 6(3), 1278-1311.

www.cnbcindonesia.com. (n.d.). Pergerakan IHSG 2018. 